\title{
The Influence Of Teacher Communication Ability On The Students' Character
}

\author{
Ahmad Nizar Rangkuti ${ }^{1}$, Luthfi ${ }^{2}$, Maulana Arafat Lubis ${ }^{3}$, Burhanuddin $^{4}$, Mariam Nasution $^{5}$ \\ \{nizarahmad1304@yahoo.com ${ }^{1}$,myluthfi.s@gmail.com²,maulanaarafat62@gmail.com ${ }^{3}$, \\ bunasty1965@gmail.com ${ }^{4}$, borunasution70@gmail.com $\left.{ }^{5}\right\}$ \\ IAIN PadangsidimpuanNorth Sumatera ${ }^{1}$, Manager of Polynelaism PDD Sibolga City RAKN Sibolga ${ }^{2}$, \\ IAIN PadangsidimpuanNorth Sumatera ${ }^{3}$, UGN Padangsidimpuan $^{4}$, IAIN PadangsidimpuanNorth \\ Sumatera
}

\begin{abstract}
The teacher is an educator who becomes a character and role model for students. Therefore, the teacher should have certain personal quality standards. In learning communication, face-to-face of a teacher has an important role in the class, namely the role in maximizing learning. The purpose of this research to know the influence of teacher communication ability on students' character at the Private MTs Bahriyatul Ulum Pandan. The kind of this research was correlational research that used ex post facto design. The population of this research was all of the students at the Private MTs BahriyatulUlumPandanconsisted of 324 students. The samples were taken by using Slovin method, which consisted of 180 students who took 60 samples through cluster random samplingtechniques of each class. The Data was collected by using a questionnaire that consisted of 30 items of each variable. Before using the instrument, the researcher tested the validity and reliability of firstly. Data collected was analyzed by using product moment correlation followed by simple linear regression and t test.Based on the calculation results of product moment correlation obtainedrhit $=0,29>\mathrm{r}_{\mathrm{tab}}=0,14$ which meant low correlation.To see the significance of the correlation used test with $t_{\text {count }}=4,07>t_{\text {table }}=1,97$. To see the effect of $X$ variable on $Y$ variable was tested by using simple linear regression with $\hat{Y}=53,504+0,314 X$. Thus, there was significant influence between teacher communication ability on students' character at the Private MTs BahriyatulUlumPandan the Regency of Central Tapanuli.
\end{abstract}

Keywords:Teacher Competency, Teacher Communication, Student's Character

\section{Introduction}

Education is a planned effort in humanizing humans. As a social being, interaction becomes a human need in everyday life. Interaction is a form of communication that seeks to convey the interests of fellow human beings. This is where the important role of communication and becomes a central point in social relations.

Communication ability get a strategic place in education world. Education is a communication in the process of involvement between two components that consist of a teacher as communicator and students as communicants. The purpose of education will be achieved if the process is communicative. 
The learning process is a process of interaction between two human elements where students as learning parties and teacher as the teaching party. The process itself is a link between teacher and students so that communication has a purpose.

Communication is a fundamental and vital social process in life. It is called fundamental because humans are social beings who need each other.[1]Syafaruddin[2] said that with communication, people will understand each other and establish love. In other words, communication has an important role in life. Good communication will produce a comfortable atmosphere, and conversely bad communication will make the situation worse.

In learning communication, face-to-face of a teacher has a very important role in maximizing learning activities in the class. There are three essential abilities that should be possessed by the teacher, they are the ability to plan activities, the ability to carry out activities and the ability to hold communication. The three abilities are called generic essential". [3] The three abilities are equally important because each teacher is not only able to plan according to design, but also they should be skilled in carrying out learning activities and they should be skilled in creating a communicative climate in learning activities.In learning communication, face-to-face of a teacher has a very important role in optimizing learning activities in the class.

Teacher competence is a teacher's ability to carry out his obligations responsibly and properly.[4] Kunandar[5] stated that competent teachers are teachers who have the required competencies to carry out educational and teaching tasks which include knowledge, attitudes, and professional skills, both personal, social and academic." Teacher competencies include pedagogical competence, social competence, and professional competence. Social competency is the teacher's ability to communicate and interact effectively with students, fellow educators, education personnel, parents/guardians of students, and surrounding community.

Based on the four of teacher competencies above that will be explored is social competencies in terms of teacher communication skills. In the field, interactions are found between teacher and students have not been implemented ideally. For example, when the learning process was taking place in the class, when the teacher was off guard, then some of studentsfought and made chaos in the class. This situation showed that the students' character is not good yet.

The term of character firstly triggered by F.W.Forester.Doni Koesoema, Pendidikan Karakter; Strategi Mendidik Anak di Zaman Modern (Jakarta: PT. Grasindo, 2007), 79.Fauziet alMaulana Arafat Lubis, "Pendidikan Kewarganegaraan Sebagai Pendidikan Demokrasi yang Berkarakter," INA-Rxiv, 2018, 5, https://doi.org/10.31227/osf.io/256v4.stated that character is a person's personality which includes moral, behavior, and character. Whereas according to psychologists, character is a system of beliefs and traditions that directs the actions of an individual.Sjarkawi, Pembentukan Kepribadian Anak; Peran Moral, Intelektual, Emosional, dan Sosial Sebagai Wujud Membangun Jati Diri (Jakarta: PT. Bumi Aksara, 2006), 11.The character is a way of thinking and behaving that becomes the characteristic of each individual to live and cooperate within in family, nation and state.Individuals who have good character are individuals who make decisions and responsible for the consequences of decisions that they make.Zubaedi, Desain Pendidikan Karakter: Konsepsi dan Aplikasinya Dalam Lembaga Pendidikan (Jakarta: Kencana, 2012), 11. It can be concluded that character is a sign or characteristic of a person that can be seen from thoughts, behavior or words. Someone who has a good character is someone who tries to do the best things about God and surrounding environment including others.

In learning process in the school, of course character becomes one of the main demands. The teacher as well as his efforts to educate well for the formation of good character of 
students. Even the teacher and the school always interact with students who are found to be problematic. However, it is still found that students say inappropriate words to fellow students easily even to the teacher as well. Then almost every teacher's day spends a lot of energy just to dissolve and reconcile the students who are fighting.

The explanation above has been explained that the teacher has made various efforts in setting a good example, but students' character was still apprehensive. Therefore, it needs to be reviewed how the influencing of teacher communication ability on the students' character.

\section{Research Methodology}

This research was conducted in Private MTs BahriyatulUlumPandan, the Regency of Central Tapanuli. The research design was correlational research usedex post facto design. The purpose of this research to find out about the influence of teacher communication ability on students' character.

The population of this research was all of students at Private MTs Bahriyatul Ulum Pandan, the Regency of Central Tapanuli that consisted of 324 students. The determination of the number of samples used the Slovin method were 180 students with cluster random sampling technique. The data collection method used in this research was a closed questionnaire by using Likertscale. This method is used to reveal the teacher communication ability and students' character.

The indicators for each variable were as follow:

Table 1. The Indicator of Teacher Communication Ability (Variable X-1)

\begin{tabular}{|c|c|c|}
\hline No & The Indicators & Sub Indicators \\
\hline 1 & $\begin{array}{l}\text { To develop;positive } \\
\text { attitudes in learning } \\
\text { activities }\end{array}$ & $\begin{array}{l}\text { Recognize the student's strength and weakness in learning } \\
\text { activities. } \\
\text { Help students to grow confidence in learning activities. } \\
\text { Help to clarify thoughts and feelings so that students can be } \\
\text { understood by students. } \\
\text { Exchange ideas in learning activities. }\end{array}$ \\
\hline 2 & $\begin{array}{l}\text { Be flexible and open in } \\
\text { learning activities }\end{array}$ & $\begin{array}{l}\text { Show an open attitude towards the opinions of students. } \\
\text { Show flexibility in adjusting. } \\
\text { Accept students as they are. } \\
\text { Show a sensitive, responsive, and sympathetic attitude towards } \\
\text { students' feelings of difficulty in learning activities. } \\
\text { Show a friendly, understanding and patient attitude towards } \\
\text { students }\end{array}$ \\
\hline 3 & $\begin{array}{l}\text { Appear passionately and } \\
\text { seriously in learning } \\
\text { activities }\end{array}$ & $\begin{array}{l}\text { Show enthusiasm in giving material or teaching, } \\
\text { Stimulate the student's interest to learn, } \\
\text { Giving the impression to students that the teacher controls the } \\
\text { material taught and how to teach (method/strategy). }\end{array}$ \\
\hline 4 & $\begin{array}{l}\text { Able to manage the } \\
\text { interaction in learning } \\
\text { activities }\end{array}$ & $\begin{array}{l}\text { Develop healthy and harmonious relationships in learning } \\
\text { activities, } \\
\text { Provide guidance so that interactions between students and } \\
\text { teachers with students are maintained well in learning activities, } \\
\text { Mastering unwanted or deviant actions in learning activities. }\end{array}$ \\
\hline
\end{tabular}


Table 2.The Indicator of Students' Character (Variable Y)

\begin{tabular}{cll}
\hline No & \multicolumn{1}{c}{ Indicators } & \multicolumn{1}{c}{ Sub Indicators } \\
\hline 1 & Religious & Carry out religious teachings \\
2 & Honest & Open to what really happened \\
3 & Tolerance & Respect differences \\
4 & Discipline & Be consistent in acting \\
5 & Hard Work & Serious effort \\
6 & Creative & Attitudes and behavior reflect innovatively \\
7 & Independent & Not dependent on others \\
8 & Democratic & Equal rights and obligations \\
9 & Curiosity & Curious attitude towards something \\
10 & National Spirit & Attitudes and actions in prioritizing nationality \\
11 & Love of country & Proud of the homeland \\
12 & Respect for achievement & Open attitude towards other achievements \\
13 & Friendship/communicative & Clever \\
14 & Peace of mind & Comfortable with calm \\
15 & Loves to read & Provide special time to read \\
16 & Cares about the environment & Take care of the environment \\
17 & Cares for the social & Care for others \\
18 & Responsible & Do their job well \\
\hline
\end{tabular}

Before the instrument is used validity and reliability tests were conducted. In testing the hypothesis using the Pearson Product Momentcorrelation formula.

\section{Research Result And Discussion}

\subsection{Teacher Communication Ability}

Communication in this research is aimed at teacher communication ability to students in learning process. The result of respondents' answer calculation to the statements submitted in questionnaire, description and quantity of statistical calculation, variable scores of students' perceptions of teacher communication ability were described as follow:

Table 3. Variable Statistical Summary of Teacher Communication ability (X-1) at Private MTs BahriyatulUlumPandan

\begin{tabular}{clc}
\hline No & \multicolumn{1}{c}{ Statistics } & Variables \\
\hline 1 & Highest score & 90 \\
2 & Lowest score & 50 \\
3 & Range & 48 \\
4 & Interval & 6 \\
5 & Number of classes & 8 \\
6 & Mean score (average) & 83,89 \\
7 & Median & 82,05 \\
8 & Mode & 81,27 \\
9 & Standard deviation & 8,54 \\
\hline
\end{tabular}




\subsection{Students' Character}

Character is a sign or characteristic of a person that could be seen from his thoughts, behavior or words. The character in this research was students' character at Private MTs BahriyatulUlumPandan. The results of respondents' answers calculation to the statements submitted in questionnaire, description and quantity of statistical calculation, variable scores of students' character were described as follow:

Tabel 4. Variable Statistical Summary of Students' Character (Y) at Private MTs Bahriyatul Ulum Pandan

\begin{tabular}{lll}
\hline No & \multicolumn{1}{c}{ Statistics } & Variables \\
\hline 1 & Highest score & 98 \\
2 & Lowest score & 44 \\
3 & Range & 54 \\
4 & Interval & 7 \\
5 & Number of classes & 8 \\
6 & Mean score (average) & 79,91 \\
7 & Median & 83,12 \\
8 & Mode & 79,58 \\
9 & Standard deviation & 8,91 \\
\hline
\end{tabular}

Based on the data description, teacher communication ability amounted to $83,89 \%$. The criteria were set it could be interpreted that $83,89 \%$ scores were in regional interval "very good". It meant that from 180 respondents, $83,89 \%$ of respondents thought that teachers at Private MTs BahriyatulUlumPandanhad excellent communication skills. After the data description, it was followed by hypothesis test. The hypothesis test result from the influence of teacher communication ability (X1) on students' character (Y) at Private MTs BahriyatulUlumPandan,the Regency of Central Tapanuli used correlation formula was concluded that there was a relationship between variable X-1 and Y with scores 0,29. Based on interpretation criteria score, the scores 0,29 was in the level 0,20-0,399. It meant low correlation.

Based on simple regression formula obtained simple regression equation $\hat{Y}=53,504+0,314 X$. The coefficient value of teacher communication ability was positive where the score was 0,314 point, it meant that if teacher communication ability increased by one point, then students' character would increase score 0,314 points. It can be seen from the contribution of teacher communication ability on students' character by $8,41 \%$ and $91,59 \%$ influenced another factor.

The research result showed that there was the influence of teacher communication ability (X1) on students' character (Y) at Private MTs BahriyatulUlumPandanthe Regency of Central Tapanuli. Based on the calculation result that had been done, the value of $t_{\text {count }}>t_{\text {table }}$ was 4,07 $>1,97$. From the data can be concluded that the correlation of variable $\mathrm{X}-1$ (teacher communication ability) with Y (students' character) was "significant".

Based on the data above, it could be understood that teacher communication ability had their own role in the formation of students' perceptions', as seen from 83-89\% of respondent stated that teacher had good communication skills. However, students' perceptions did not become the main influence on students' character at Private MTs BahriyatulUlumPandan. It was evidenced by the acquisition of the correlation score and low contribution. So, 8,41\% of students' character was influenced by teacher communication ability. 


\section{Conclusion}

From the research conducted by the researcher it can be concluded that based on data analysis by using product momentcorrelation. Then followed by multiple correlations. In this analysis, the level of validity is $5 \%$ and $\mathrm{N}=180$. Based on the calculation result of product moment $\mathrm{X}_{1}$ against $\mathrm{Y}$ obtained $\mathrm{r}_{\text {count }}=0,29$ for $\mathrm{r}_{\text {table }}=0,14$. Sor $\mathrm{r}_{\text {count }}>\mathrm{r}_{\text {table }}$ is at the level 0,20 0,399 . It means low correlation. Fort $\mathrm{count}=4,07$ andt $\mathrm{table}_{\text {ta }}=1,97$ so $\mathrm{t}_{\text {count }}>\mathrm{t}_{\text {table. }}$. Thus, there is the influence of teacher communication ability on students' character at Private MTs BahriyatulUlumPandanthe Regency of Central Tapanuli by contributing $8,41 \%$.

\section{References}

[1] J. Rakhmat, Psikologi Komunikasi. Bandung: Remaja Rosdakarya, 2005.

[2] Syafaruddin, Manajemen Organisasi Pendidikan Perspektif Sains dan Islam. Medan: Perdana Publishing, 2017.

[3] T. A. Baca, "Komunikasi Guru.".

[4] M. Syah, Psikologi Pendidikan dengan Pendekatan Baru. Bandung: PT Remaja Rosdakarya, 2005.

[5] Kunandar, Guru Profesional: Implementasi KTSP dan Persiapan Menghadapi Sertifikasi Guru. Jakarta: PT RajaGrafindo Persada, 2007.

[6] D. Koesoema, Pendidikan Karakter; Strategi Mendidik Anak di Zaman Modern. Jakarta: PT. Grasindo, 2007.

[7] M. A. Lubis, "Pendidikan Kewarganegaraan sebagai Pendidikan Demokrasi yang Berkarakter," INA-Rxiv, 2018.

[8] Sjarkawi, Pembentukan Kepribadian Anak; Peran Moral, Intelektual, Emosional, dan Sosial Sebagai Wujud Membangun Jati diri. Jakarta: PT. Bumi Aksara, 2006.

[9] Zubaedi, Desain Pendidikan Karakter: Konsepsi dan Aplikasinya Dalam Lembaga Pendidikan. Jakarta: Kencana, 2012. 